\title{
Description of the larva of Niponius osorioceps Lewis, 1885 (Coleoptera: Histeridae) with first data on chaetotaxy of Niponiinae
}

\section{Описание Аичинки Niponius osorioceps Lewis, 1885 (Coleoptera: Histeridae) и первые сведения о хетотаксии Niponiinae}

\author{
A.A. Zaitsev ${ }^{1}$, A.I. Zaitsev ${ }^{2}$ \\ A.А. Зайцев ${ }^{1}$, А.И. Зайџев

\begin{abstract}
${ }^{1}$ Moscow State Pedagogical University, Institute of Biology and Chemistry, Department of Zoology and Ecology, Kibaltchicha str. 6-3, 129164 Moscow, Russia. E-mail: ztema@mail.ru

${ }^{2}$ Moscow City University, Institute of Natural Sciences and Sport Technologies, Department of Biology and Human Physiology, Chechulina st. 1, 105568 Moscow, Russia. E-mail: azaitzev@mail.ru

${ }^{1}$ Московский Педагогический Государственный Университет, Институт Биологии и Химии, кафедра зоологии и экологии, ул. Кибальчича 6-3, 129164 Москва, Россия.

2 Московский городской педагогический университет, Институт естествознания и спортивных технологий, кафедра биологии и физиологии человека, ул. Чечулина 1, 105568 Москва, Россия.
\end{abstract}

KEY WORDS. Niponius, Histeridae, larva, chaetotaxy, morphology.

КЛЮЧЕВЫЕ СЛОВА. Niponius, Histeridae, личинка, хетотаксия, морфология.

ABSTRACT. Previosly unknown last instar larva of Niponius osorioceps Lewis, 1885 is described from Southern Primorie, Russia, including data on larval chaetotaxy of Niponiinae Gyllenhal, 1808. Position of this subfamily within Histeridae is discussed.

РЕЗЮМЕ. Впервые описана личинка последнего возраста Niponius osorioceps Lewis, 1885. Приводятся данные о хетотаксии личинок Niponiinae Gyllenhal, 1808. Обсуждается положение подсемейства в системе Histeridae.

\section{Introduction}

Niponiinae Fowler, 1912 is a small subfamily of Histeridae Gyllenhal, 1808, consisting of a single genus Niponius Lewis, 1885 with 21 species distributed worldwide, mostly in Japan and India [Beutel, Leschen, 2016]. Larvae of two species were described so far (both based on final instar): $N$. andrewesi Lewis, 1893 from India [Gardner, 1930], and N. obtusiceps Lewis, 1885b, from Japan [Hayashi, 1986]. These descriptions were rather detailed for that time, with notes on prepupal and pupal stages [Gardner, 1930], but it is natural that no detailed study of chaetotaxy was performed. The importance of chaetotaxy characters in study of systematic and phylogeny of various groups of beetles was stated by a number of authors [Ashe, Watrous, 1984; Bosquet, Goulet, 1984; Alaire, 1990; Makarov, 2002]. The first extensive study of chaetotaxy of histerid larvae was performed by Kovarik and Passoa [1993]. They developed a setal nomenclature for the first instar of representatives of 7 histerid subfamilies (Onthophilinae MacLeay, 1819, Tribalinae Bickhardt, 1914, Histerinae Gyllenhal, 1808, Dendrophilinae Reitter, 1909, Abraeinae MacLeay, 1819, Saprininae Blanchard, 1845, Trypanaeinae Marseul, 1857) and showed the principal conservatism of chaetome in these groups. Chaetotaxy of Hetaeriinae Marseul, 1857 larvae was later studied by Caterino and Tishechkin [2006] and its relatively high resemblance with above mentioned authors' data was pointed out. Thus, chaetotaxy of larval Histeridae was not studied for Chlamydopsinae Bickhardt, 1914, Trypeticinae Bickhardt, 1913, which larvae are undescribed at present, and Niponiinae.

During the study of beetles fauna of Lazovskyi reserve, previously unknown last instar larvae of Niponius osorioceps were found. Larvae were collected together with pupae and adults under the bark of Acer sp., in burrows of Hylesinus tristis Blandford, 1894 (Curculionidae: Scolytinae) and reared to adult in laboratory (Figs 1-2). In the present paper we provide description of the larva, including data on chaetotaxy, first time for Niponiinae.

How to cite this article: Zaitsev A.A., Zaitsev A.I.2019. Description of the larva of Niponius osorioceps Lewis, 1885 (Coleoptera: Histeridae) with first data on chaetotaxy of Niponiinae // Russian Entomol. J. Vol.28. No.2. P.148-157. doi: 10.15298/rusentj.28.2.06 


\section{Material and methods}

Habitus photographs were taken with a Canon EOS 40D camera with a MP-E $65 \mathrm{~mm}$ macro lens. Photos of slide mounts were taken with Canon EOS 6D camera attached to a Carl Zeiss AXIO Scope.A1 microscope. All photos were processed using Zerene Stacker software. Line drawings were made in Corel Draw 12. The specimens were preserved in $70 \%$ ethanol or on slides with Faure's Berlese media and are deposited in Moscow State Pedagogical University, Moscow, Russia (MSPU). Setal nomenclature follows Kovarik and Passoa [1993]: setae are referred to by two capital letters with corresponding numbers, pores coded with two capital letters and a lower case letter (for convenience, pores on figures are designated only by a lower case letter). Groups of setae are coded by two capital letters preceded by a lower case "g". A code followed by a question mark "?" indicates that we are uncertain with homology of this structure with such in Kovarik and Passoa paper.

The following abbreviations for sclerites and appendages were used in this paper: AP — anterior pleurite; $\mathrm{CO}$ - coxa; $\mathrm{ES}$ - episternite; EM - epimeron; FE - femur; FR - frontal sclerite; HT - humeral tergite; LA - labium; LP — lateral presternite; LS lateral sternite; LT - lateral tergite; $\mathrm{MN}$ - mandible; MX - maxilla; MsT - mesothoracic tergite; MtT metathoracic tergite; PC - precoxite; PL — posterior pleurite; PP — pygopod; PR — presternum; PS presternite; PT — prothoracic tergite; ST — sternite; TE - tergite; TI - tibiotarsus; TR - trochanter; UG - urogomphus. For detailed definitions of sclerites see Kovarik and Passoa [1993]. Also, several additional abbreviations were used for other structures: AM ampulla; AEM1-3 - epimeral apodeme of pro-, meso, and metathorax; AES1-3 - episternal apodeme of pro-, meso-, and metathorax; APL1 — pleural apodeme of prothorax; EB - egg burster; PE — penicillus; SD — digitiform sensilla; SE — sensorium; TF — tentorial fossa.

\section{Results}

Niponius osorioceps Lewis, 1885

Figs 2-15.

MATERIAL. 30 larvae together with pupae and adults: Russia, Southern Primorie, Lazovskyi reserve, Proselochnaya cordon, mid-

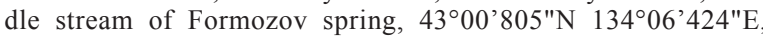
19.VIII.2007, leg. \& det. K. Makarov, A. Zaitsev (MSPU).

DESCRIPTION. Last instar larva. Maximum body length about $12 \mathrm{~mm}$; head length $0.9 \mathrm{~mm}$; urogomphi length $0.2 \mathrm{~mm}$; maximum width of thorax $1 \mathrm{~mm}$; maximum width of abdomen $1.1 \mathrm{~mm}$. Body elongated, cylindrical; widest across abdominal segments II-VI, slightly tapering posterad; urogomphi small, 2-jointed. Head capsule brownish-yellow, its lower part somewhat lighter; mandibles reddish-brown, sclerotized parts of antenna, labial and maxillary palpi light brown. Pronotum yellowish-brown, straw-yellow along the edges. Meso- and metanotum lighter, from brownish-yellow to straw-

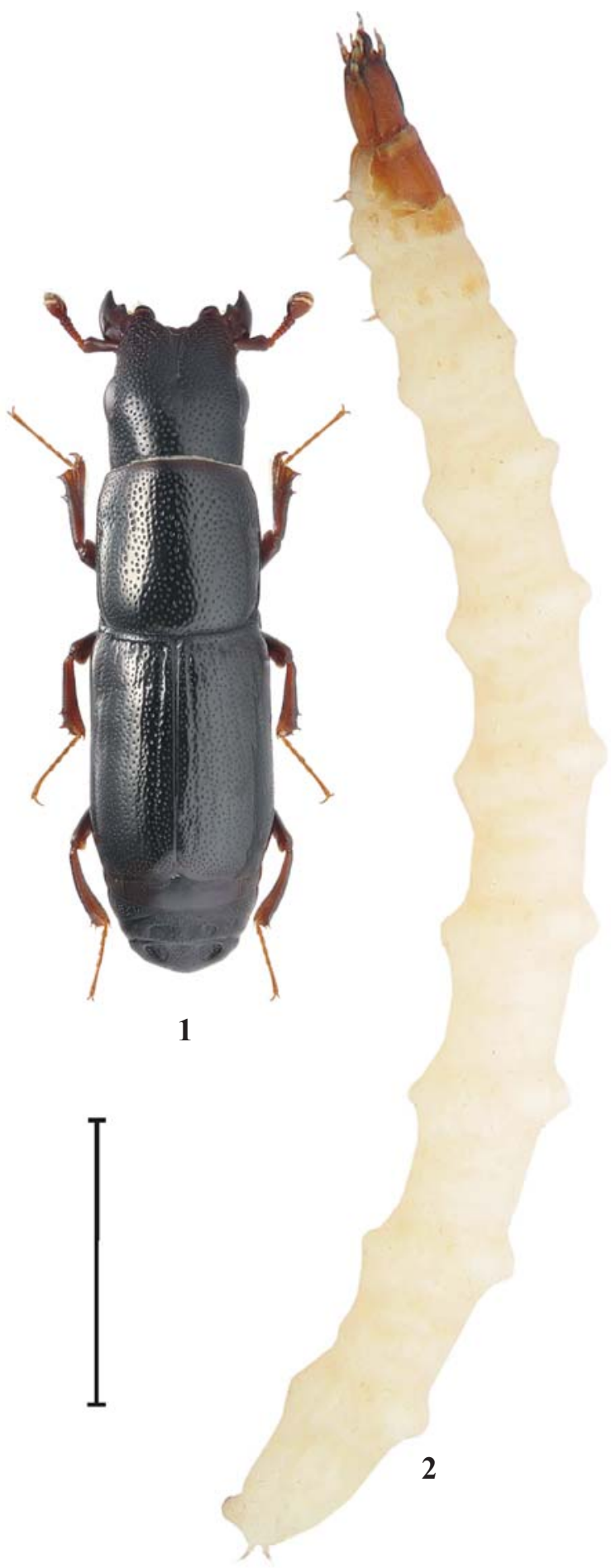

Figs 1-2. Niponius osorioceps, habitus: 1 - adult male, dorsal; 2 - larva, lateral. Scale bar: $2.0 \mathrm{~mm}$

Рис. 1-2. Niponius osorioceps, общий вид: 1 - самец, сверху; 2 - личинка, сбоку. Масштаб: 2,0 мм.

yellow. Pleurites pale yellow, prothoracic sclerites brownishyellow, sclerotized parts of legs light brown. Abdominal sclerites pale yellow, barely distinguishable from membrane. Abdominal segments IX-X have the same coloration, only distal urogomphal joints more pigmented, yellowish-brown. 
Membranous area of thoracic and all abdominal segments except IX-X covered in numerous short asperities. Tergite of abdominal segment I with a pair of heavy sclerotized egg bursters. Abdominal segments II-VIII on dorsal and ventral sides with paired ampulla (Fig. 2).

Head capsule (Fig. 3): prognathous, protracted, subrectangular, slightly narrowed posteriorly and deeply emarginated at base. Dorsal surface of each parietal sclerite with concave area which marked by sclerotized ridge; epicranial suture rather long, about 0.2 as long as head capsule; frontal sutures short, V-shaped. Ventral tentorial pits confluent at middle forming tentorial fossa. Stemmata absent.

Chaetotaxy of head capsule (Fig. 3). Frontal sclerite on each side with 11 separate setae: 8 microsetae (FR1-FR7, FR9) and 3 mesosetae (FR8, FR10-11); one setal group of 5 mesosetae (gFR) located on anterolateral margin. Also 5 pores present (FRa-FRd, FRf). Nasale (Fig. 4) asymmetrical, with 2 small teeth, each with microseta and 1 larger teeth with 2 microsetae. Also a pair of subfrontal mesosetae (SF) located ventrally near each lateral margin of nasale. Each parietal sclerite dorsally with 11 setae: 5 microsetae (PA12-PA14, PA16-PA20), mesoseta PA15 and 2 macrosetae (PA21-22); also 3 pores present (PAg-PAi). Ventrally each parietal sclerite with 8 setae: 2 microsetae (PA28-29), 4 mesosetae (PA24, PA26-27, PA30) and 2 macrosetae (PA23, PA25); also 7 pores present (PAl, PAn; PAo-PAs).

Antenna (Fig. 6) with 3 antennomeres, about 0.6 as long as greatest head width. Antennomere I 1.9 as long as wide, its sclerotized area with 4 pores: $\mathrm{ANa}$, ANc near inner edge; $\mathrm{ANb}, \mathrm{ANd}$ near outer edge. Antennomere II 0.8 as long as antennomere I and about 1.8 as long as wide, with single pore $\mathrm{ANe}$ on sclerotized area; distal membrane with 2 conical sensoria (SE1-2) and 5 papillate sensilla, 3 located on outer edge close to SE2, and other 2 on inner edge near the base of antennomere III. Antennomere III 0.5 as long as antennomere II and twice as long as wide, its apex with 2 small and 3 larger papillate sensilla surrounding conical sensorium.

Mandible (Fig. 5) narrowed, falcate, 1.8 as long as basal width, unidentate, incisor area with well developed retinaculum. Macroseta MN1 located one third from base, vestigal seta MN2 located dorsally near apex, group of penicillus setae (PE) with 9 long plumose setae and 3 shorter nonplumose setae. Also 3 pores present: $\mathrm{MNa}$ located dorsally approximately in the middle of the mandible, $\mathrm{MNb}$ - dorsolaterally from $\mathrm{MNa}, \mathrm{MNc}$ - near the base of retinaculum.

Maxilla (Fig.7). Stipes 1.8 as long as wide, with 6 setae (MX1-6), setal group (gMX1) and 4 pores (MXa-d): microseta MX1 on inner edge near the base of stipes; 3 mesosetae: MX2 located-ventrally one third from base, MX5-6 dorsally on distal membrane; 2 macrosetae: MX3 located ventrally two third from base, MX4 ventrally on outer edge, near distal membrane; gMX1 consists of 10 plumose setae on inner edge. Distal membrane of stipes with 4 dorsal elongated spines (flexible nonplumose setae sensu Kovarik and Passoa [1993]). Pores MXa-b, MXd ventral, pore MXc dorsal, all located on sclerotized part of stipes. Palpifer 1.1 as long as wide, with single macroseta MX7 ventral on outer edge; 2 pores (MXe-f) and 2 elongated spines dorsal on distal membrane. Galea about 4 as long as wide with 2 apical setae: mesoseta MX8 dorsal and microseta MX9 ventral. Palpomere I 0.6 as long as palpifer, almost as long as wide, with single ventral pore MXg. Palpomere II 0.8 as long as palpomere I, almost as long as wide, with single ventral pore MXh and 4 pore-like sensilla. Palpomere III almost as long as palpomere II, about 1.7 as long as wide, dorsally with digitiform sensilla (SD), ventrally with 2 pore-like sensilla; its apex with 8 short basiconical sensilla.
Labium (Fig.7). Mentum reduced, its distal part membranous, dorsally with group of about 20 plumose setae (gLA); proximal part sclerotized. Prementum almost as long as wide, base of dorsal surface with numerous teeth; on each side with obtuse spinose lobe bearing 4 teeth, distal one is significantly larger than others. Prementum with 2 setae and 2 pores: macroseta LA2 located ventrally on sclerotized part of prementum near the distal membrane and mesoseta LA3 on dorsal distal membrane; it is possible that seta ?LA1 reduced to pore and located dorsally near the base of prementum; LAa situated close to LA2, LAb dorsal on sclerotized part. 3 porelike and 1 short peg-like sensilla flanking LA3. Labial palpomere I 1.3 as long as wide, with single pore-like sensilla on distal membrane. Palpomere II 1.3 as long as palpomere I, almost 2.5 as long as wide, with digitiform sensilla dorsally and 3 pore-like sensilla on sclerotized part. Its apex with 7 basiconical sensilla, central one is the largest.

Thorax (Fig. 8): about 0.2 as long as total body length, widest across mesothorax. Prothorax is 0.8 as long as wide and 1.2 as long as meso- and metathorax.

Prothorax. Prothoracic tergite (PT) with well sclerotized trapezoidal pronotal shield, medial ecdysial line distinct. Pronotal shield with 10 setae on each side: 4 macrosetae (TE2-3, TE5, TE9), mesoseta TE4 and 5 microsetae (TE1, TE7-8, TE10-11). Also 9 pores present (TEa-i). Rest of PT with 10 setae on each side: 5 macrosetae (TE16, TE18-19, TE21, TE23), 4 microsetae (TE17, TE20, TE24, TE27), seta ?TE15 visible as pore. Also 4 pores present (TEj, TEk-m). Each episternite (ES) with 2 microsetae (PL34-35) close to procoxal cavity. Each epimeron (EM) with single microseta ST40. Presternite (PS) roughly quadrate, with 2 microsetae (PR7, PR9) on each side; each lateral presternite (LP) triangular, about twice as long as PS, with 3 microsetae (PR1, PR4-5) and macroseta PR6. Prosternite (ST) diamond-shaped, its central area with smooth cuticle. Each side with 3 setae: mesoseta ST46, 2 microsetae (ST30, ST44). Laterosternites (LS) small, oval, without setae; precoxite not distinct, 2 microsetae (ST31-32) on each side. Short asperities cover the area between each laterosternite and prosternum.

Mesothorax. Mesothoracic tergite (MsT) with well sclerotized roughly rectangular mesonotal shield, medial ecdysial line distinct. Numerous short asperities located on anterior sternum and between humeral and lateral tergites. Mesonotal shield on each side with 2 microsetae (TE10-11) and a single pore TEf. Rest of MsT with 6 setae on each side: 3 macrosetae (TE4-5, TE9), mesoseta TE8 and 2 microsetae (TE3, TE7). Also 2 pores $(\mathrm{TEj}-\mathrm{h})$ present. Each humeral tergite (HT) with 4 microsetae (TE1-2, TE13-14) and 4 pores (TEa-c, 1 unassociated pore). Each lateral tergite (LT) with 7 setae: 3 macrosetae (TE16, TE18-19) and 4 microsetae (TE15, TE17, TE20-21). Also a single pore TEj present. Each anterior pleurite (AP) with 2 microsetae (PL23-24). Thoracic spiracle (Fig. 11) surrounded by AP, annular-biforous. Each posterior pleurite (PL) subdivided in 2 plates, anterior without setae, posterior about twice as long and bears macroseta PL27 and microseta PL28. Each ES with 2 microsetae (PL34-35) close to procoxal cavity. Each EM with single microseta ST40. Precoxite not distinct, 2 microsetae present (ST31-32) on each side. LS elongated, much larger than on prothorax, without setae. Mesosternite (ST) roughly oval, with 3 setae on each side: macroseta ST46 and 2 microsetae (ST30, ST44).

Metathorax. Metathoracic tergite (MtT) with well sclerotized rectangular metanotal shield, medial ecdysial line poorly seen. Numerous short asperities located on anterior part of the whole segment. Metanotal shield on each side 


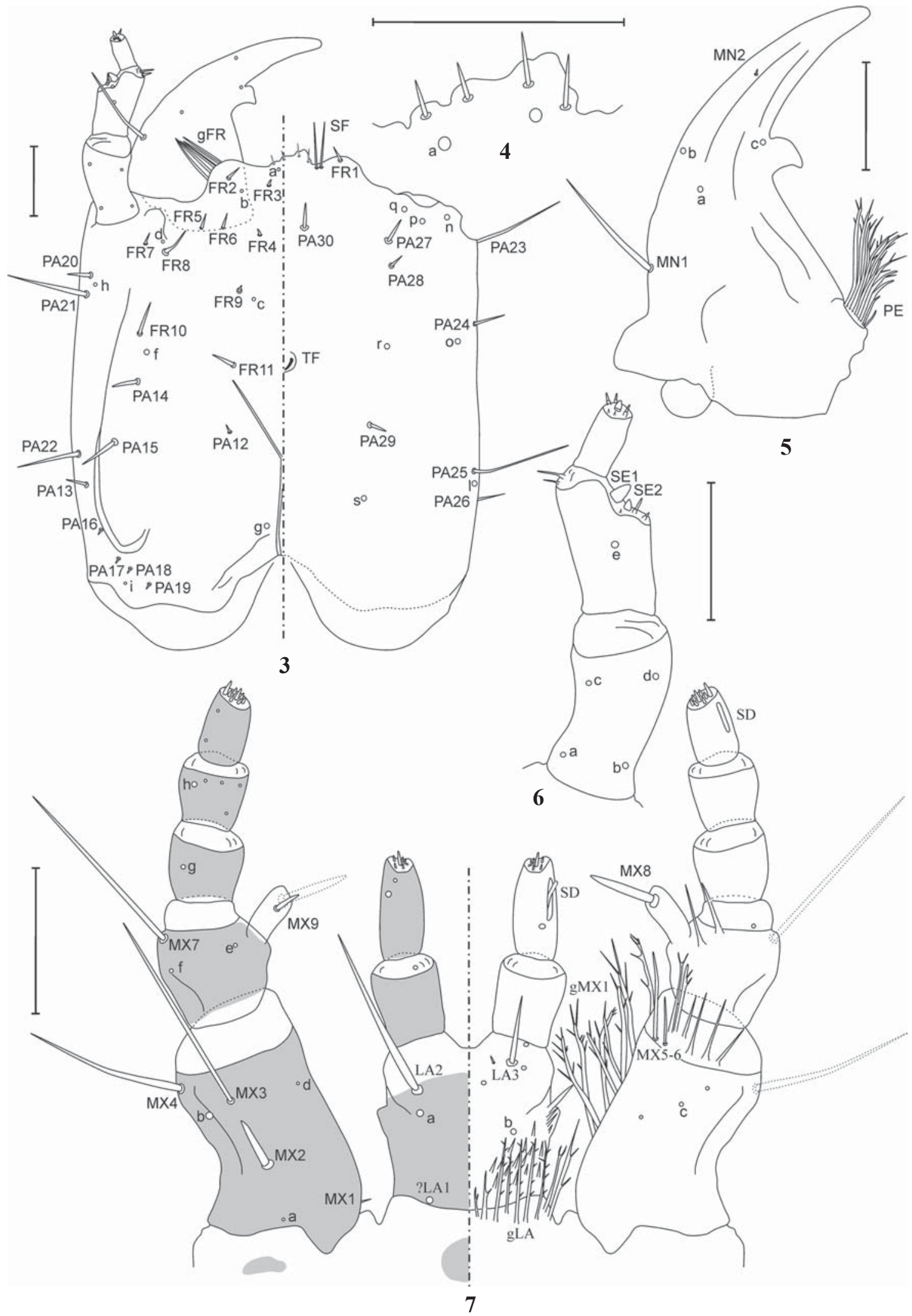

Figs 3-7. Niponius osorioceps, larva: 3 - head, left — dorsal, right — ventral; 4 - nasale, ventral; 5 - left mandible, dorsal; 6 - right antenna, dorsal; 7 - labio-maxillar complex, left — ventral, right - dorsal. Scale bars: $0.1 \mathrm{~mm}$.

Рис. 3-7. Niponius osorioceps, личинка: 3 - голова, слева — сверху, справа - снизу; 4 - назале, снизу; 5 - левая мандибула, сверху; 6 - правая антенна, сверху; 7 - лабио-максиллярный комплекс, слева - снизу, справа - сверху. Масштаб: 0.1 мм. 


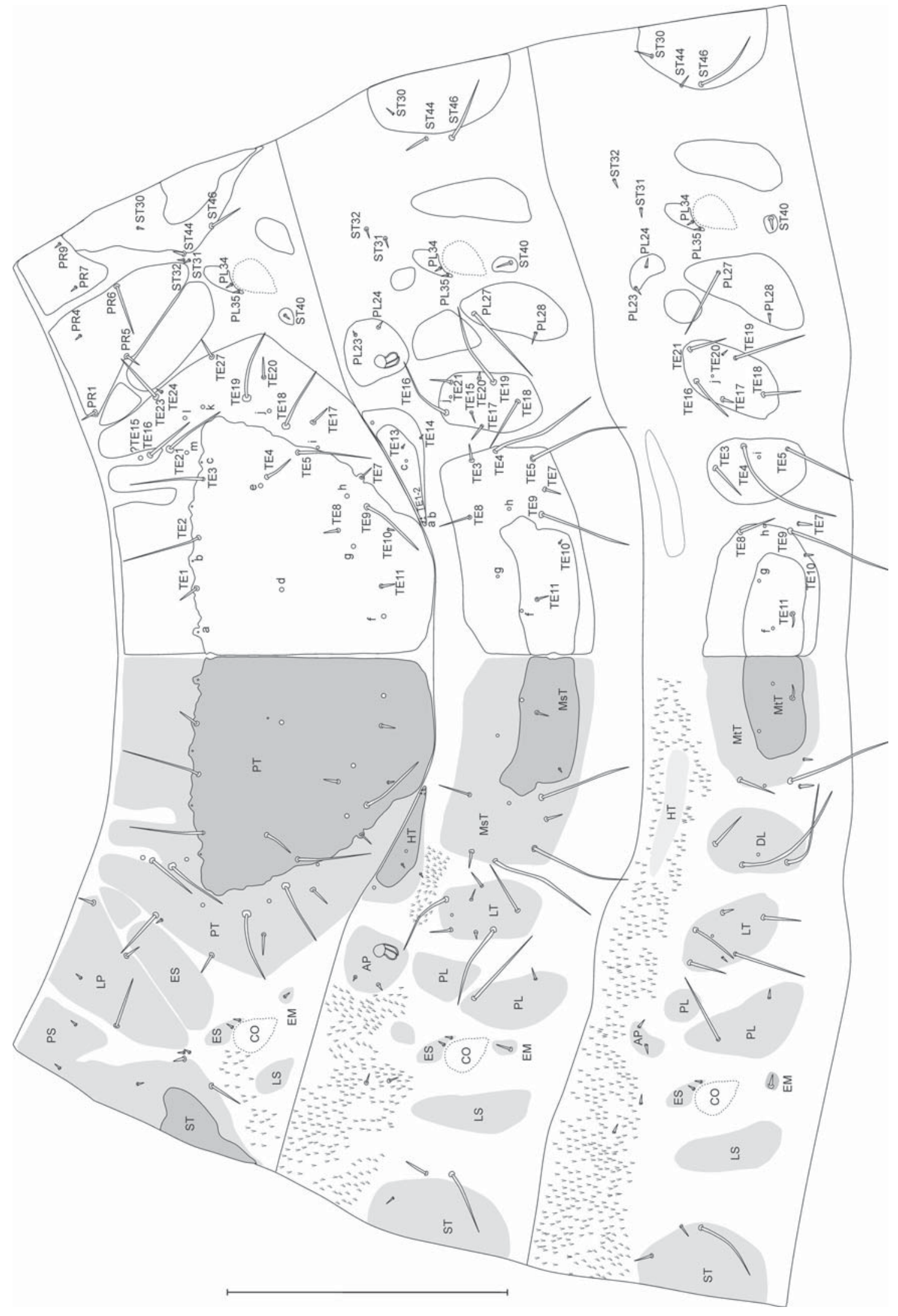

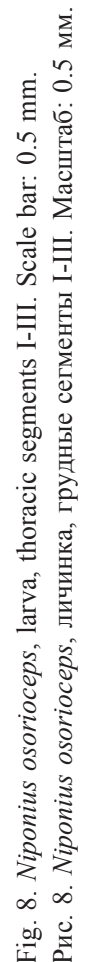


with single microseta TE11 and 2 pores (TEf-g). Rest of MtT with 4 setae on each side: macroseta TE9, mesoseta TE8 and 2 microsetae (TE7, TE10); also a single pore TEh present. Humeral tergites very pale, without setae. Dorsolateral tergites (DL) well developed, oval, each with 3 setae: 2 macrosetae (TE4-5) and mesoseta TE3; also a single pore TEi present. Chaetotaxy of the rest metathoracic sclerites is the same as on mesothorax except the absence of TE15 on LT.
Legs short, five-jointed, similar in form and chaetotaxy. Length ratio of its joints to coxa is $0.5: 0.8: 1.1: 1.7$. Mesothoracic leg (Fig. 9): coxa with 11 setae: 5 macrosetae (CO11, CO15-16, CO18-19), 3 mesosetae (CO12-14) and 3 microsetae (CO1-3). Pores not visible. Trochanter with microseta TR1, mesoseta TR 3 and 4 pores (TRa-b, TRd-e). Femur with 7 mesosetae (FE2-8) and 2 pores (FEa-b). Tibiotarsus with 17 microsetae (TI1-17) and a single pore TIb. A single claw styliform, about 1.4 as long as tibiotarsus, without setae.
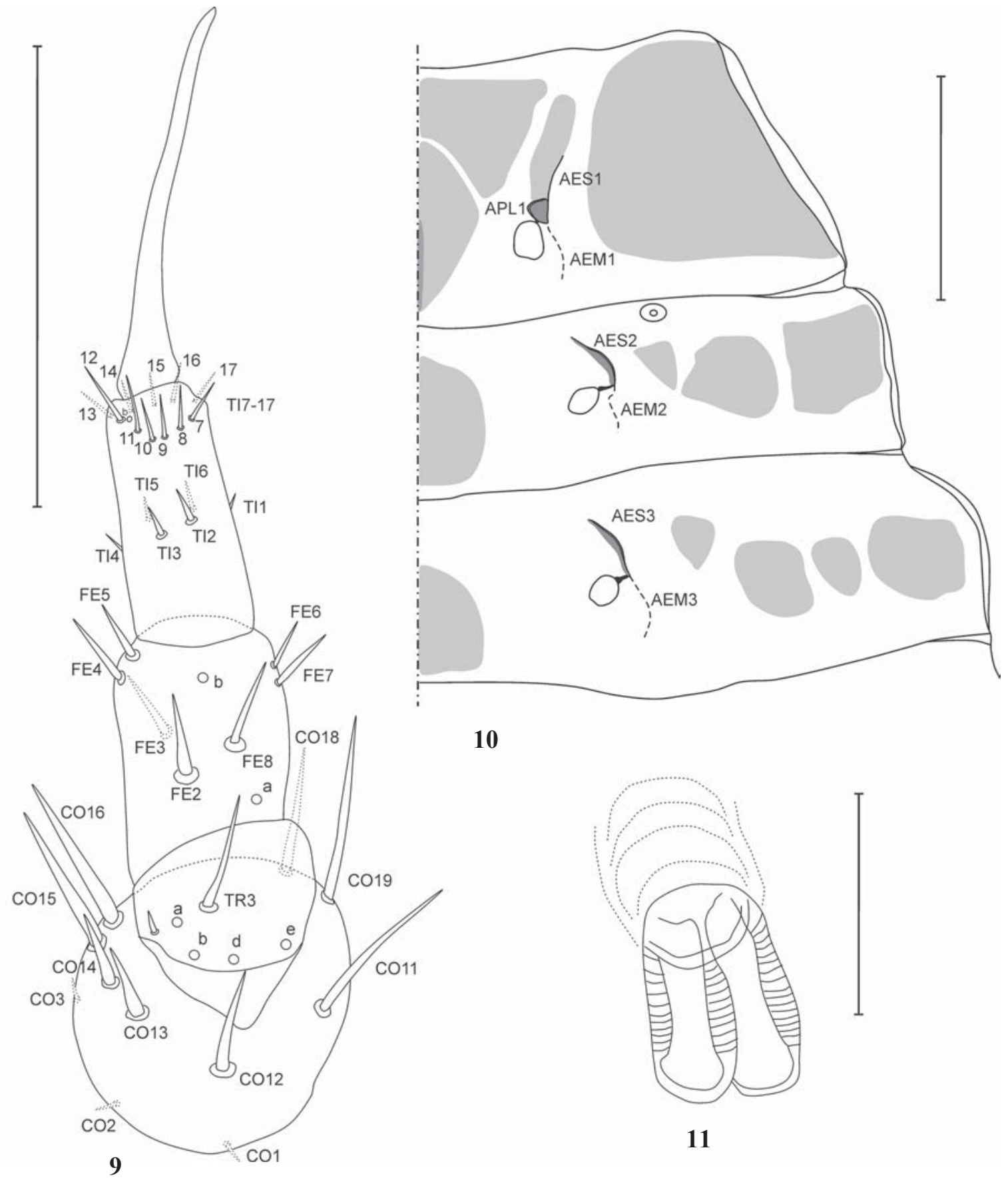

10

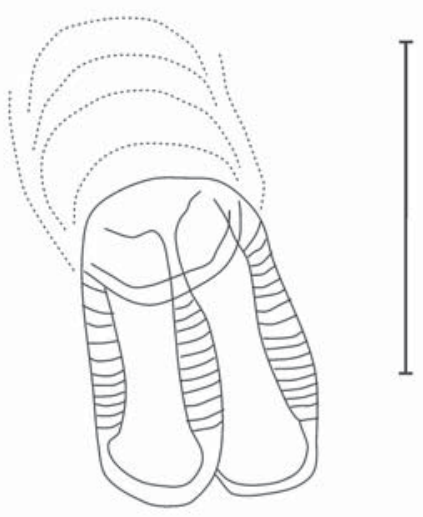

11

Figs 9-11. Niponius osorioceps, larva: 9 - mesothoracic leg, ventral; 10 - thoracic endoskeleton; 11 - thoracic spiracle. Scale bars: $0.1 \mathrm{~mm}$ for $9 ; 0.5 \mathrm{~mm}$ for $10 ; 0.05 \mathrm{~mm}$ for 11 .

Рис. 9-11. Niponius osorioceps, личинка: 9 - нога 2-ой пары, снизу; $10-$ эндоскелет грудных сегментов; $11-$ грудное дыхальце. Масштаб: 0,1 мм для 9; 0,5 мм для 10; 0,05 мм для 11. 


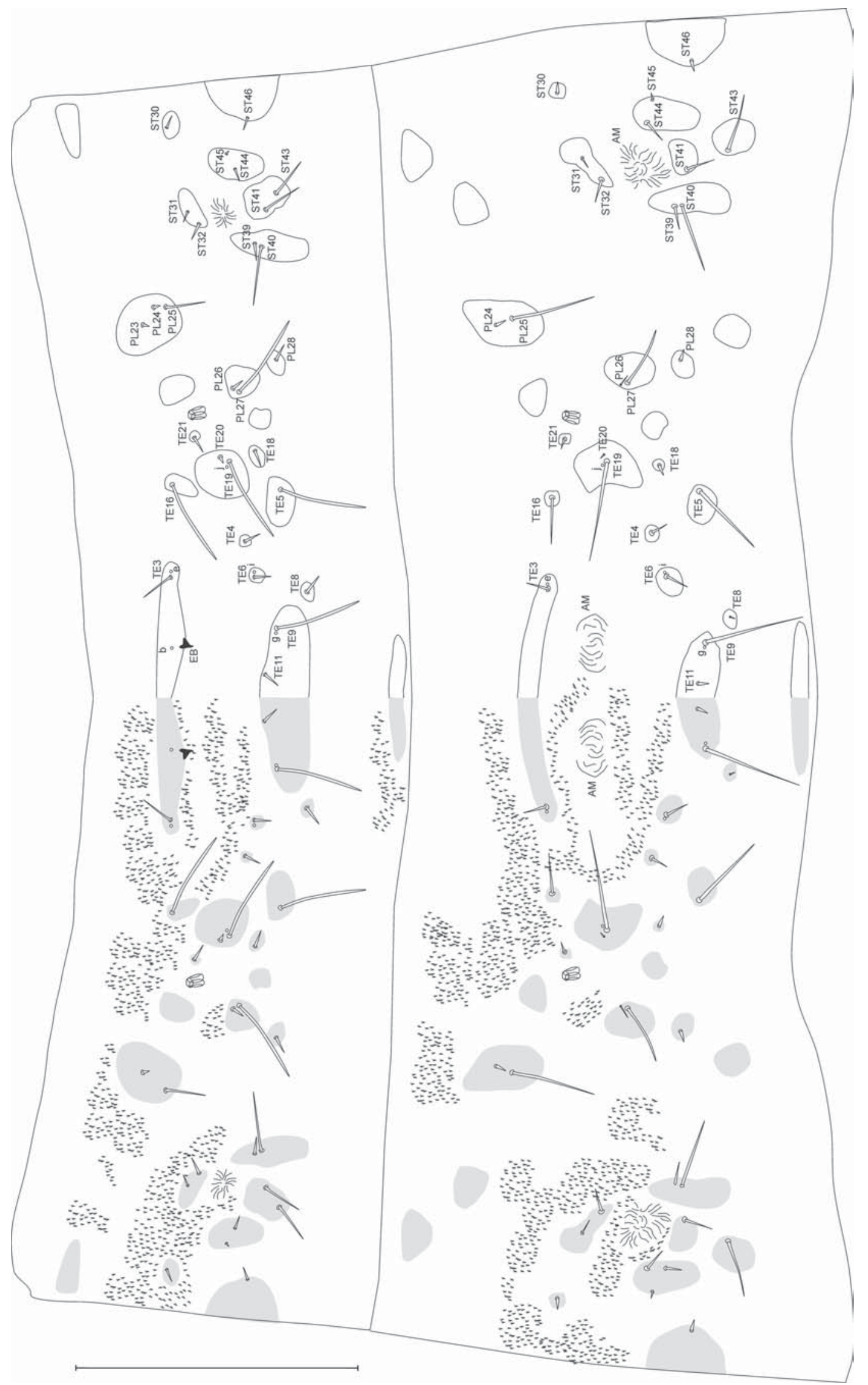

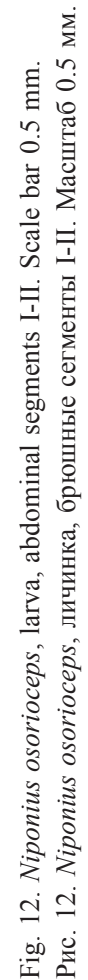


Thoracic endoskeleton (Fig. 10): prothorax with poorly-developed episternal and epimeral apodemes; pleural apodeme triangular, narrowed apically, profurcae and spinae absent. Meso- and metathorax with poorly-developed episternal and epimeral apodemes; pleural apodemes reduced; meso- and metathoracic furcae absent, meso- and metathoracic spinae absent. Such simple structure of the thoracic endoskeleton corresponds with other studied representatives of the family.

Abdomen. Abdominal segment I (Fig. 12). Tergum with 9 paired sclerites and 3 single sclerites: median sclerite, sclerite with egg bursters and posterior tergite; on each side with 12 setae and 5 pores. Each sclerite with egg burster bears single mesoseta TE3 and 2 pores: TEb located near egg burster, and TEe adjoined TE3. Large median sclerite with macroseta TE9, mesoseta TE11 and pore TEg adjoined TE9. There are 3 small and 1 medsized sclerites on each side of large median sclerite. Most closely situated small sclerite with single mesoseta TE8; another small sclerite anteriad of TE8 with mesoseta TE6 and adjoined pore TEi; third small sclerite laterad of TE6 with mesoseta TE4. Medsized sclerite with macroseta TE5. Each lateral tergite subdivided into 5 sclerites; the largest one with macroseta TE19, microseta TE20 and pore TEj adjoined TE19. Sclerite located anteriad to TE19 with macroseta TE16; posterior sclerite with mesoseta TE18; the smallest sclerite with mesoseta 21. Sclerite situated laterad of TE18 without setae. Pleuron on each side with 4 sclerites and 6 setae. Anterior pleurite is the largest sclerite with macroseta PL25 and 2 microsetae (PL23-24); lesser sclerite with macroseta PL27 and microseta PL26; the smallest sclerite with mesoseta PL28. Sclerite located between anterior pleurite and spiracle without setae. Sternum on each side with 6 sclerites and 10 setae; also single median sclerite present. Anterior sternite without setae; median sternite with microseta ST46; small sclerite located between anterior and median sternites with microseta ST30. There are 4 sclerites surrounding ventral ampulla: anterior sclerite with 2 microsetae (ST31-32); posterior with 2 macrosetae (ST41, ST43); larger lateral sclerite with macroseta ST40 and microseta ST39; lesser lateral sclerite with 2 microsetae (ST4445). Numerous short asperities located mostly in anterior half of the segment.

Abdominal segment II similar to I, but differs in better developed tergal and sternal ampulla; lack of egg bursters; pleuron on each side with additional sclerite without setae; anterior pleurite without PL23; anterior part of sternum with one additional sclerite on each side, without setae; each sclerite, posterior to ventral ampulla subdivided into two, one with ST41, other with ST43. Abdominal spiracles similar to those on thorax, annual-biforous (Fig. 11). Abdominal segments III-VIII like segment II.

Abdominal segment IX (Figs 13-14) without ampulla and asperities. Tergum with 8 setae and 6 sclerites on each side. 2 mesosetae (TE3, TE21) and 2 macrosetae (TE9,
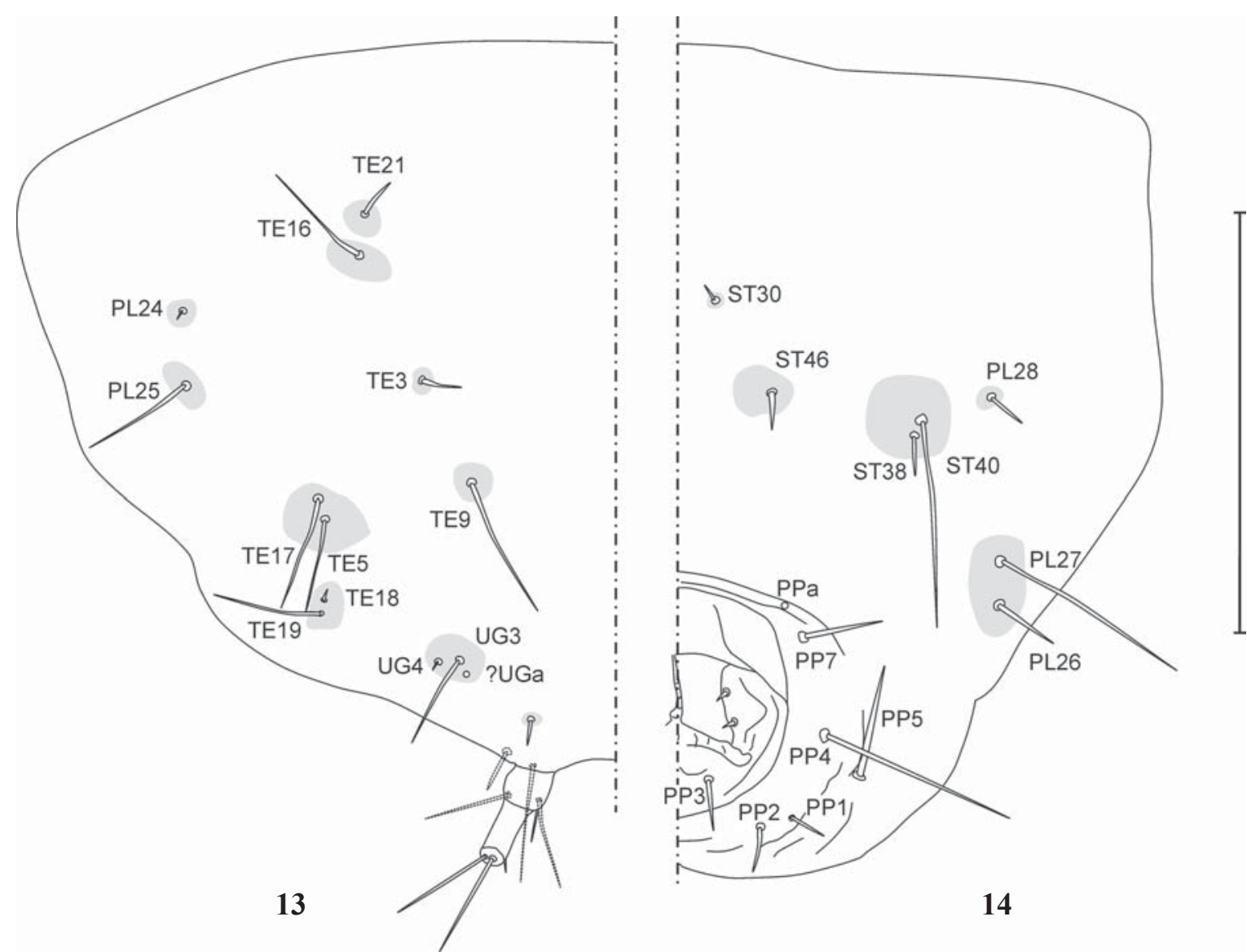

Figs 13-14. Niponius osorioceps, larva: 13 - abdominal segment IX, dorsal; 14 - abdominal segments IX-X, ventral. Scale bar: 0.5 $\mathrm{mm}$ for $13-14$.

Рис. 13-14. Niponius osorioceps, личинка: 13 - IX сегмент брюшка, сверху; 14 - IX и X сегменты брюшка, снизу. Масштаб: 0,5 мм для $13-14$. 


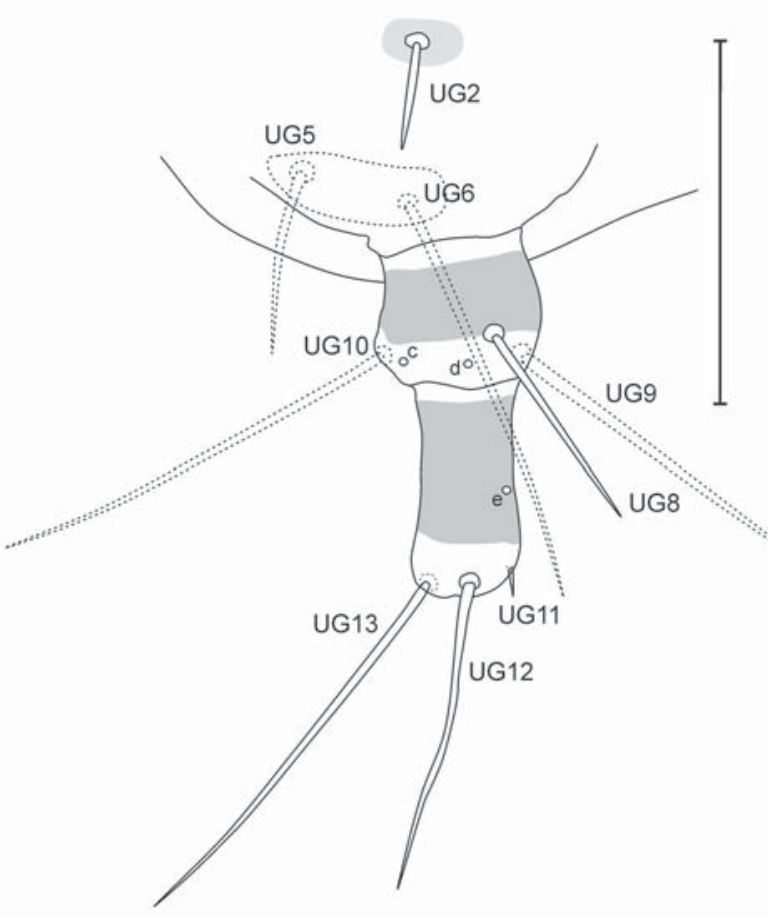

Fig. 15. Niponius osorioceps, larva, right urogomph, dorsal. Scale bar $0.2 \mathrm{~mm}$.

Рис. 15. Niponius osorioceps, личинка, правая урогомфа, сверху. Масштаб 0,2 мм.

TE16) each located on small sclerite; 2 macrosetae (TE5, TE17) both located on midsized sclerite; microseta TE18 and macroseta TE19 both located on a small sclerite. Pleuron with 5 setae and 4 sclerites on each side. Microseta PL24, mesoseta PL28 and macroseta PL25 each located on small sclerite; mesoseta PL26 and macroseta PL27 both located on midsized sclerite. Sternum with 4 setae and 3 sclerites on each side. Microseta ST30 on minute anterior sclerite, mesoseta ST46 on small sclerite; mesoseta ST38 and macroseta ST40 both on midsized sclerite. Urogomphi (Fig. 15) 2-jointed, basal urogomphal sclerites dorsally with microseta UG4, macroseta UG3 and pore ?UGa sharing midsized sclerite, and separate mesoseta UG2 closer to urogomphal joint I; ventrally with mesoseta UG5 and macroseta UG6 closer to urogomphal joint I. Urogomphal joint I almost as long as wide, its apical part dorsally with mesoseta UG8 and pores UGc-d on distal membrane, ventrally with 2 macrosetae (UG9-10). Urogomphal joint II 2.5 as long as wide and almost 1.5 as long as urogomphal joint I, its apical part dorsally with macroseta UG12, ventrally with microseta UG11 and macroseta UG13; pore UGe located dorsally on sclerotized part

Abdominal segment X (Fig. 14) short, considerably retracted and directed posteroventrally, without asperities, sclerites not distinct. On each side with 8 setae: 2 previously undiscribed apical microsetae; 5 mesosetae (PP1-3, PP5, PP7) and single macroseta PP4 surrounding abdominal segment X. A single pore PPa present in anterolateral part of the segment.

BIOLOGY. Numerous larvae were found crawling in galleries of Hylesinus tristis, feeding on its larvae and pupae.

\section{Discussion}

Larvae of Niponiinae can be easily distinguished from other histerids by the following characters: cylindrical body with well developed dorsal and ventral ampulla on abdominal segments II-VIII, legs with very long styliform claw, and presence of egg bursters in final larval instar. The latter character was observed in all described Niponius larvae and can be preliminary explained as the result of substitution of original function with the need of additional structures for the fixation of the body within bark beetles' galleries, but further study, including first instar larva is necessary.

No principal differences between larva of $N$. osorioceps and those of $N$. andrewesi and N. obtusiceps can be found, cause of rather simplified drawings made by both authors (Gardner, 1930, Hayashi, 1986). The only obvious difference between $N$. osorioceps and $N$. obtusiceps larvae is the presence of additional macroseta on maxillary palpifer of the latter.

Larval chaetotaxy of $N$. osorioceps in many details matches with the generalized plan for the family, which was suggested by Kovarik and Passoa [1993]. However we could not locate some setae and pores (see table). Most of missing setae are microsetae and in some cases we even could not recognize sclerites on which they should be present, or they were barely distinguishable from membrane and lack setae. In the meantime practically no unique setae, which were absent in Kovarik and Passoa' description of Onthophilus, were found, with the exclusion of paired microsetae on abdominal segment X.

Position of Niponiinae in the system of Histeridae is controversial. Some authors [Ohara, 1994, Slipinski, Mazur, 1999] considered highly specialized subcortical forms to be primitive and refer to this group as basal. However, only limited number of adult characters were used, with no information on larvae. In the study on the phylogeny of the family by Caterino and Vogler [2002] adult and larval characters were used, as well as molecular data. Authors proposed that basal histerids were unspecialized and that subcortical forms have appeared repeatedly during the family's evolution. Thus, Niponiinae not counted as basal group of the family, and this place was occupied by Onthophilus Leach, 1817 (Onthophilinae) or Anapleus Horn, 1873 (Dendrophilinae). No doubt, that the use of larval and molecular characters besides adult ones is preferable for making certain phylogenetic conclusions. Unfortunately, there were several issues in this study. First, some important larval characters, such as number of setae on claw and presence/absence of dorsobasal teeth on labrum were not coded for Niponius. Second, some larval characters of other histerid larvae were incorrectly stated, for example absence of setae on claw in Hololepta Paykull, 1811. Moreover, molecular data on Niponius was absent.

If we agree with the basal position of Onthophilinae, then we have to recognize larval chaetome of Onthophilus to be the most closely related to the ancestral 
Table. Setae and pores, missing in last instar larva of $N$. osorioceps in comparison with generalized plan for the family

[Kovarik, Passoa, 1993]

Таблица. Хеты и поры генерализованного плана для семества [Kovarik, Passoa, 1993], отсуствующие у личинки последнего возраста $N$. osorioceps

\begin{tabular}{|c|c|c|c|c|c|c|c|c|}
\hline & $\begin{array}{l}\text { Head } \\
\text { capsule } \\
\text { and } \\
\text { mouthparts }\end{array}$ & Prothorax & $\begin{array}{l}\text { Meso- } \\
\text { thorax }\end{array}$ & $\begin{array}{l}\text { Meta- } \\
\text { thorax }\end{array}$ & Leg & $\begin{array}{l}\text { Abdominal } \\
\text { segments } \\
\text { I-VIII }\end{array}$ & $\begin{array}{l}\text { Abdominal } \\
\text { segment } \\
\text { IX and } \\
\text { urogomphi }\end{array}$ & $\begin{array}{l}\text { Abdominal } \\
\text { segment } X\end{array}$ \\
\hline Setae & $\mathrm{gMX} 2$ & $\begin{array}{l}\text { TE12-13; } \\
\text { PR2-3, } \\
\text { PR8; } \\
\text { ST36 }\end{array}$ & $\begin{array}{l}\text { ST29, } \\
\text { ST36 }\end{array}$ & $\begin{array}{l}\text { TE1- } \\
2, \text { TE13- } \\
15 ; \text { PL25; } \\
\text { ST29, ST } \\
36-37, \\
\text { ST39 }\end{array}$ & $\begin{array}{l}\text { CO4- } \\
10, \\
\text { CO17; } \\
\text { TR2, } \\
\text { TR5-6; } \\
\text { FE1; } \\
\text { TA1-2 }\end{array}$ & $\begin{array}{l}\text { TE1, TE7, } \\
\text { TE10, } \\
\text { TE13-15, } \\
\text { TE17; } \\
\text { ST29, } \\
\text { ST33-36, } \\
\text { ST38, } \\
\text { ST42 }\end{array}$ & $\begin{array}{l}\text { TE1; } \\
\text { ST36; } \\
\text { UG1, UG7 }\end{array}$ & PP6 \\
\hline Pores & $\begin{array}{l}\text { FRe, PAj, } \\
\text { PAk, PAm }\end{array}$ & TEk & $\begin{array}{l}\text { TEe, } \\
\text { TEi }\end{array}$ & TEb, TEe & $\begin{array}{l}\text { COa-c; } \\
\text { TRa, } \\
\text { TRf; } \\
\text { TIa }\end{array}$ & - & $\begin{array}{l}\text { TEf, TEg; } \\
\text { UGb }\end{array}$ & - \\
\hline
\end{tabular}

state for the family. This point of view confirmed by the fact that chaetome and sclerites pattern of Onthophilus is very similar to that of Syntelia histeroides Lewis, 1882 (Synteliidae), which is generally recognized as the most primitive representative of Histeroidea. In this case, reduction of number of setae, such as gMX2, TA1-2 and others (see table), as well as certain sclerites in Niponius larvae should be considered as secondary loss and thus progressive characters.

However, a number of larval features of Niponius, such as dorsal and ventral ampulla on abdominal segments II-VIII, and well developed egg bursters in last instar cannot be for sure considered as progressive. That means that the position of this problematic group is still uncertain and further study is needed, including description of the first instar larva as well as obtaining of molecular data.

Acknowledgements. We thank K.V. Makarov (MSPU) for providing the adult photo of $N$. osorioceps and for valuable comments during the preparation of the manuscript.

\section{References}

Alaire Y. 1990. Primary setae and pores on the cephalic capsule and head appendages of larval Hydroporinae (Coleoptera: Dytis- cidae: Hydroporinae) // Canadian Journal of Zoology. Vol.69. P.2255-2265.

Ashe J.S., Watrous L.E. 1984. Larval chaetotaxy of Aleocharinae (Staphylinidae) based on a description of Atheta coriaria Kraatz // Coleopterist Bulletin. Vol.38. P.165-179.

Beutel R., Leschen R. (eds.). 2016. Handbook of Zoology. Arthropoda: Insecta. Coleoptera, Beetles. Volume 1: Morphology and Systematics (Archostemata, Adephaga, Myxophaga, Polyphaga partim). 2nd edition. Berlin, Boston: De Gruyter. 684 pp.

Bosquet Y., Goulet H. 1984. Notation of primary setae and pores on larvae of Carabidae (Coleoptera: Adephaga) // Canadian Journal of Zoology. Vol.62. P.573-588.

Caterino M. S., Vogler A. P. 2002. The phylogeny of the Histeroidea // Cladistics. Vol.18. P.394-415.

Caterino M., Tishechkin A. 2006. DNA identification and morphological description of the first confirmed larvae of Hetaeriinae (Coleoptera: Histeridae) // Systematic Entomology. Vol.31. P.405-418.

Gardner J.C.M. 1930. The early stages of Niponius andrewsi // Bulletin of Entomological Research. Vol.21. P.15-17.

Kovarik P.W., Passoa S. 1993. Chaetotaxy of larval Histeridae based on a description of Onthophilus nodatus LeConte // Annals of the Entomological Society of America. Vol.86. P.560-576.

Makarov K.V. 2002. [Chaetotaxic markers in the evolutionary morphology of carabid larvae] // Russian Entomological Journal. Vol.11. No.1. P.23-34 [in Russian].

Hayashi N. 1986. [Larvae] // Morimoto K., Hayashi N. (eds.). The Coleoptera of Japan in Color. Hoikusha Publishing Co.: Osaka. Vol.1. P.202-218, pls.1-113 [in Japanese].

Ohara M. 1994. A revision of the superfamily Histeroidea of Japan // Insecta Mastumurana. Vol.51. P.1-283.

Ślipiński S.A., Mazur S. 1999. Epuraeosoma, a new genus of Histerinae and phylogeny of the family Histeridae // Annales Zoologici. Vol.49. P.209-230. 